of the exhibits of the Telford Centenary Exhibition in London have been re-arranged at Aberdeen for the benefit of members of the British Association.

\section{Scientific Institutions in South Africa}

Ax a meeting of the Royal Society of South Africa on June 20, Mr. L. Crawford read a paper on the South African Literary and Scientific Institution (1833-1857). The South African Literary Society was started in 1824; John Fairbairn and Thomas Pringle were two of its sponsors, but it encountered the hostility of the Governor, Lord Charles Somerset. He refused to grant it a licence and the project was dropped until 1829. The Society then began to hold meetings, papers were read and prizes offered for essays, one of these being limited to students of the South African College, founded in the same year. The South African Institution was founded also in 1829 on the same lines, and in $\mathbf{1 8 3 2}$ the two societies amalgamated, becoming the South African Literary and Scientific Institution. Reports of the meetings and papers read appeared in the South African Quarterly Journal, but in 1835 that Journal came to an end and information about the later history of the Institution is difficult to find. The Institution's own minute books, etc., have disappeared. In 1834, Sir John Herschel arrived in South Africa. He was a strong supporter of the Institution during the four years he was there; for nearly three years he was president. $\mathrm{He}$ specially pressed the claims of meteorology on the Institution. In 1836 the Cape Almanac speaks of the rooms of the Institution and its Museum. After 1838 it is certain the Institution declined, so much that in $1850 \mathrm{John}$ Fairbairn suggested in the Commercial Advertiser that a new Institution be formed and for permanence should be attached to the public library. This appeal met with no response. The Institution disappeared from the list of societies in the Almanac and Annual Register in 1858, so it may be taken that it came to an end in 1857, but from the first annual report of the South African Museum in 1856 it is learned that, in the previous year, what was left of its collections, books, etc., had been handed over to the Museum.

\section{River Gauging}

THE agitation on behalf of the establishment of a national Inland Water Survey will be supported during the meeting of the British Association at Aberdeen by a series of demonstrations of the process of river gauging on the River Dee, which are being undertaken by Capt. W. N. McClean with the aid of his apparatus, employed on the survey of the Ness Basin, and apparatus used by Prof. S. M. Dixon in connexion with gaugings of the River Severn. The demonstrations will take place on September 11 and other dates, as may be found desirable, at Woodend, above the Cairnton Intake of the Aberdeen Water Supply, the water authority of Aberdeen having kindly co-operated in providing a site for the gaugings and by installing two water-level recorders at Cairnton and Cults. Woodend Reach is of the 'pool' type and about 200 feet in width at normal water level. The maximum surface velocity is expected to vary from $3 \mathrm{ft}$. per sec. at low water to $10 \mathrm{ft}$. per sec. on a normal flood. At low water the depth on the section is $3 \mathrm{ft}$. over the greater part with a deeper strip on the south side. The two types of gauging apparatus to be employed are (1) the Ness Basin type consisting of a ropeway, twin punts and stream-lined rod with current meter on the lower end, and (2) the Severn type, consisting of a ropeway with suspended current meter and sinker weight. A comparison of the two methods under identical conditions promises to provide useful data for inland water survey purposes.

\section{A Survey of Aberdeen}

For the Aberdeen meeting of the British Association, a pamphlet has been prepared entitled "A Scientific Survey of Aberdeen and District", and presented to all members. This marks a continuation of the policy adopted last year at Leicester. These slight volumes of uniform size and type are more convenient and, be it said, more useful than the varied and often ponderous handbooks that in former years were distributed at each centre of meeting. The new series gives a wealth of information without a bewildering mass of detail. Various authors have contributed to the work: Mr. J. McFarlane contributes a geographical introduction, followed by Prof. A. W. Gibb and Dr. A. Bremner on the geology, Prof. J. Ritchie on the animal life and Mr. A. MacGregor on the flora. A number of articles treat of archæology, agriculture and the various industries of the town and district. Many members will turn with interest to the chapters on the fishing and granite industries which have done so much for the modern development of Aberdeen. The article on the trades shows, however, that Aberdeen has various other thriving industries, some with obvious local associations such as shipbuilding and fertilisers and others of more recent development. A final chapter gives biographical notes on some of the better-known men of science associated with the north-east of Scotland.

\section{Alcoholism and Male Mortality}

AN informative paper on this subject was read by Dr. Rudolf Bandel, of Nuremberg, before the recent International Congress on Alcoholism held on July 30-August 3 in London. Prof. Bandel stated that Hindhede in 1923 was the first to demonstrate the considerable fall in the male death rate in Denmark associated with the decrease in the consumption of alcohol brought about by the War. A similar fall in the male mortality along with decrease in alcohol consumption has been observed elsewhere, for example, in Germany, Belgium, Sweden, Hungary, the United States, and in a lesser degree in Switzerland, Holland and Norway. It was not so marked in the last three countries, because either, it is suggested, the decrease in alcohol consumption during the War was not so pronounced, or else the alcohol consumption before the War was not so high as in the other countries. On the other hand, in countries such as Italy and Spain, which did not reduce their alcohol consumption during the War, the male 